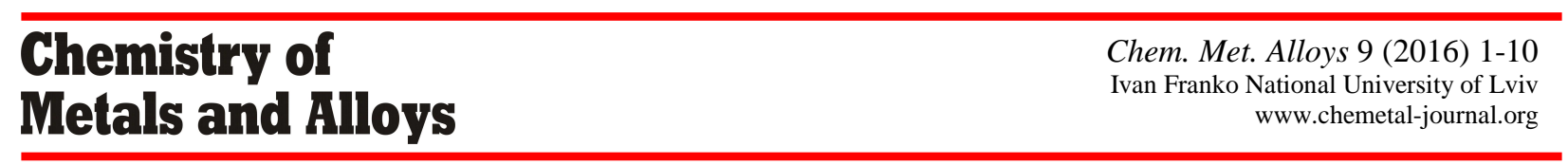

\title{
The Y-Ni-Cu ternary system at $600^{\circ} \mathrm{C}$
}

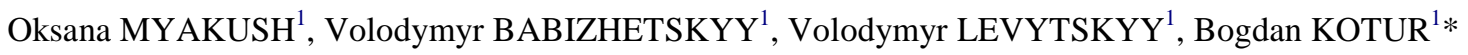 \\ ${ }^{1}$ Department of Inorganic Chemistry, Ivan Franko National University of Lviv, \\ Kyryla i Mefodiya St. 6, 79005 Lviv, Ukraine \\ * Corresponding author.E-mail: kotur@lnu.edu.ua
}

Received April 6, 2016; accepted June 29, 2016; available on-line November 7, 2016

The isothermal section of the $\mathrm{Y}-\mathrm{Ni}-\mathrm{Cu}$ phase diagram at $600^{\circ} \mathrm{C}$ has been investigated by means of $\mathrm{X}$-ray diffraction and microstructure analyses. The homogeneity ranges of the solid solutions $\mathrm{YNi}_{5-x} \mathrm{Cu}_{x}(0 \leq x \leq 4.6)$ (structure type $\mathrm{CaCu}_{5}$, space group $\left.P 6 / \mathrm{mmm} a=0.48861(2)-0.50080(4), c=0.39592(2)-0.40740(4) \mathrm{nm}\right)$, $\mathrm{Y}_{2} \mathrm{Ni}_{17-x} \mathrm{Cu}_{x}(0 \leq x \leq 7.8)$ (structure type $\mathrm{Th}_{2} \mathrm{Ni}_{17}$, space group $P 6_{3} / m m c, a=0.8314(1)-0.8387(1), c=0.8042(1)-$ $0.8117(1) \mathrm{nm}$ ), $\mathrm{YCu}_{6-7} \mathrm{Ni}_{x}(0 \leq x \leq \mathbf{0 . 2 8})$ (structure type $\mathrm{TbCu}_{7}$, space group $P 6 / \mathrm{mmm}, a=0.49470(4)-$ $0.49540(4), c=0.4133(4)-0.4227(4) \mathrm{nm})$ were refined. It was found that the maximal solubility of the third component does not exceed 3.8 at. $\%$ in $\mathrm{Y}_{2} \mathrm{Cu}_{7}$ and less than 1 at.\% in $\mathrm{Y}_{2} \mathrm{Ni}_{7}, \mathrm{YCu}$, and $\mathrm{YCu}_{4}$. The crystal structure of a single crystal of composition $\mathrm{YNi}_{4} \mathrm{Cu}\left(\mathrm{YNi}_{5-x} \mathrm{Cu}_{x}\right.$ solid solution) was investigated by $\mathrm{X}$-ray diffraction: $a=0.4899(2), c=0.3979(3) \mathrm{nm}, R_{1}=0.028$ for 57 independent reflections with $I_{0} \geq 2 \sigma\left(I_{0}\right)$, $w R_{2}=0.058$. A new ternary compound, $\mathrm{YNi}_{2.85-0.75} \mathrm{Cu}_{1.15-3.25}$, of unknown structure with an extended homogeneity range, was found.

Intermetallics / Rare-earth metal system / Phase diagram / X-ray diffraction

\section{Introduction}

The phase equilibria in the $\mathrm{Y}-\mathrm{Ni}-\mathrm{Cu}$ ternary system have previously been investigated near the $\mathrm{Ni}-\mathrm{Cu}$ side with low content of $\mathrm{Y}(\leq 16.7$ at.\%) at $500^{\circ} \mathrm{C}$ [1], and in the whole concentration range at $600^{\circ} \mathrm{C}$ [2] by X-ray diffraction (XRD), and at $700^{\circ} \mathrm{C}$ using diffusion couples and key alloys [3]. The isothermal sections of the $\mathrm{Y}-\mathrm{Ni}-\mathrm{Cu}$ phase diagram at $600^{\circ} \mathrm{C}$ [2] and at $700^{\circ} \mathrm{C}$ [3] are presented in Fig. 1 a,b.

A large number of studies of the ternary $\mathrm{Y}-\mathrm{Ni}-\mathrm{Cu}$ system were dedicated to the crystal structures [4-12], magnetism [6], hydrogen sorption [7-9], and electrical $[10,11]$ properties of the solid solutions based on the binary $\mathrm{Y}-\mathrm{Ni}$ and $\mathrm{Y}-\mathrm{Cu}$ compounds. However, there are some significant differences between the results of these studies. The authors of [2] reported the existence of two ternary compounds at the isoconcentrate of 50 at.\% Y, whereas in [3] the existence of extended solid solutions between the isostructural binary compounds $\mathrm{YNi}$ and $\mathrm{YCu}$ (both indicated as FeB structure type) was found. The data on the crystal structures and the homogeneity ranges of some solid solutions based on the binary compounds of the $\mathrm{Y}-\mathrm{Ni}$ and $\mathrm{Y}-\mathrm{Cu}$ systems are contradictory (see Table 1). In particular, the results of [2] differ significantly from the data of $[1,3-6,12]$.
The binary systems $\mathrm{Ni}-\mathrm{Cu}[13-15], \mathrm{Y}-\mathrm{Ni}[16-24]$ and $\mathrm{Y}-\mathrm{Cu}$ [25-32], which form the ternary $\mathrm{Y}-\mathrm{Ni}-\mathrm{Cu}$ system, have been widely studied, including the phase diagrams over the whole concentration ranges. The $\mathrm{Ni}-\mathrm{Cu}$ system [13] is a simple isomorphous system with continuous liquid and solid solutions separated by a narrow two-phase region. The data on some of the binary $\mathrm{Y}-\mathrm{Ni}$ and $\mathrm{Y}-\mathrm{Cu}$ compounds are contradictory, in particular as they were investigated under different conditions.

The $\mathrm{Y}-\mathrm{Ni}$ phase diagram was first investigated by Beaudry and Daane [16] using metallographic and thermal analyses and $\mathrm{X}$-ray diffraction. The existence of nine binary compounds $\mathrm{Y}_{2} \mathrm{Ni}_{17}$ (unknown structure), $\mathrm{YNi}_{5}$ (structure type (ST) $\mathrm{CaCu}_{5}$, space group (SG) $P 6 / \mathrm{mmm}$ ), $\mathrm{YNi}_{4}$ (unknown structure), $\mathrm{Y}_{2} \mathrm{Ni}_{7}$ (unknown structure), $\mathrm{YNi}_{3}$ (ST $\mathrm{PuNi}_{3}$, $\mathrm{SG} R-3 m), \mathrm{YNi}_{2}\left(\mathrm{ST} \mathrm{MgCu}_{2}, \mathrm{SG} F d-3 m\right)$, YNi (ST $\mathrm{FeB}$, SG Pnma), $\mathrm{Y}_{3} \mathrm{Ni}_{2}\left(\mathrm{ST} \mathrm{Y}_{3} \mathrm{Ni}_{2}, \mathrm{SG} P 4_{1} 2{ }_{1}\right)$, and $\mathrm{Y}_{3} \mathrm{Ni}$ (ST $\mathrm{Fe}_{3} \mathrm{C}$, SG Pnma) was detected. Later, Buschow [17] reported the crystal structure of the compound $\mathrm{Y}_{2} \mathrm{Ni}_{17}\left(\mathrm{ST} \mathrm{Th}_{2} \mathrm{Ni}_{17}, \mathrm{SG} P 6_{3} / m m c\right)$. The phase $\mathrm{YNi}_{4}$ with unknown structure was not found in $[2,23,24,33]$, but is present on the phase diagrams of the binary and ternary systems reported in [3,16,22,25]. The authors of [19-21] reported two types of structure for $\mathrm{Y}_{2} \mathrm{Ni}_{7}$ : a hexagonal structure of the $\mathrm{Ce}_{2} \mathrm{Ni}_{7}$ type $\left(\mathrm{SG} \mathrm{Pb}_{3} / m m c\right.$ ) and a rhombohedral structure of the $\beta-\mathrm{Gd}_{2} \mathrm{Co}_{7}$ type (SG $R-3 m$ ). 

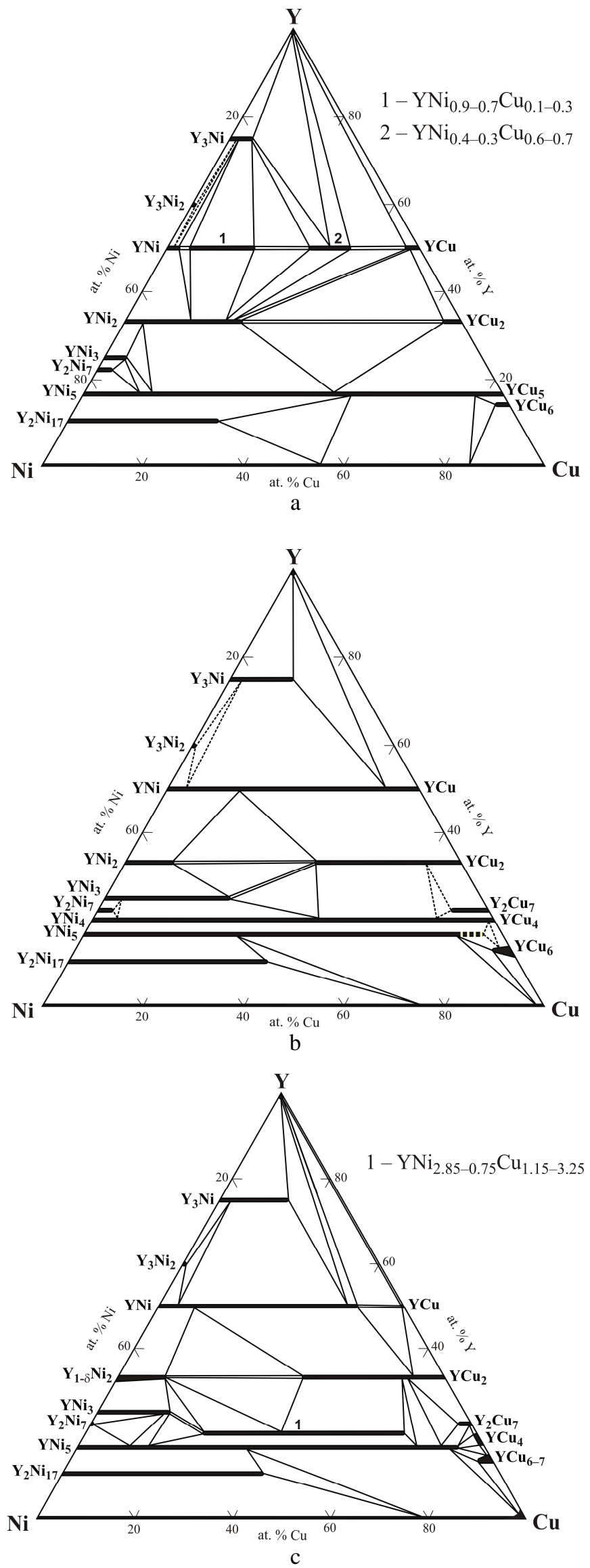

Fig. 1 Isothermal sections of the $\mathrm{Y}-\mathrm{Ni}-\mathrm{Cu}$ system at $600^{\circ} \mathrm{C}$ [2] (a), $700^{\circ} \mathrm{C}$ [3] (b), and $600^{\circ} \mathrm{C}$ (present investigation) (c). 
Table 1 Crystallographic data and solubility of the third component in solid solutions based on the binary $\mathrm{Y}-\mathrm{Ni}$ and $\mathrm{Y}-\mathrm{Cu}$ compounds in the $\mathrm{Y}-\mathrm{Ni}-\mathrm{Cu}$ system.

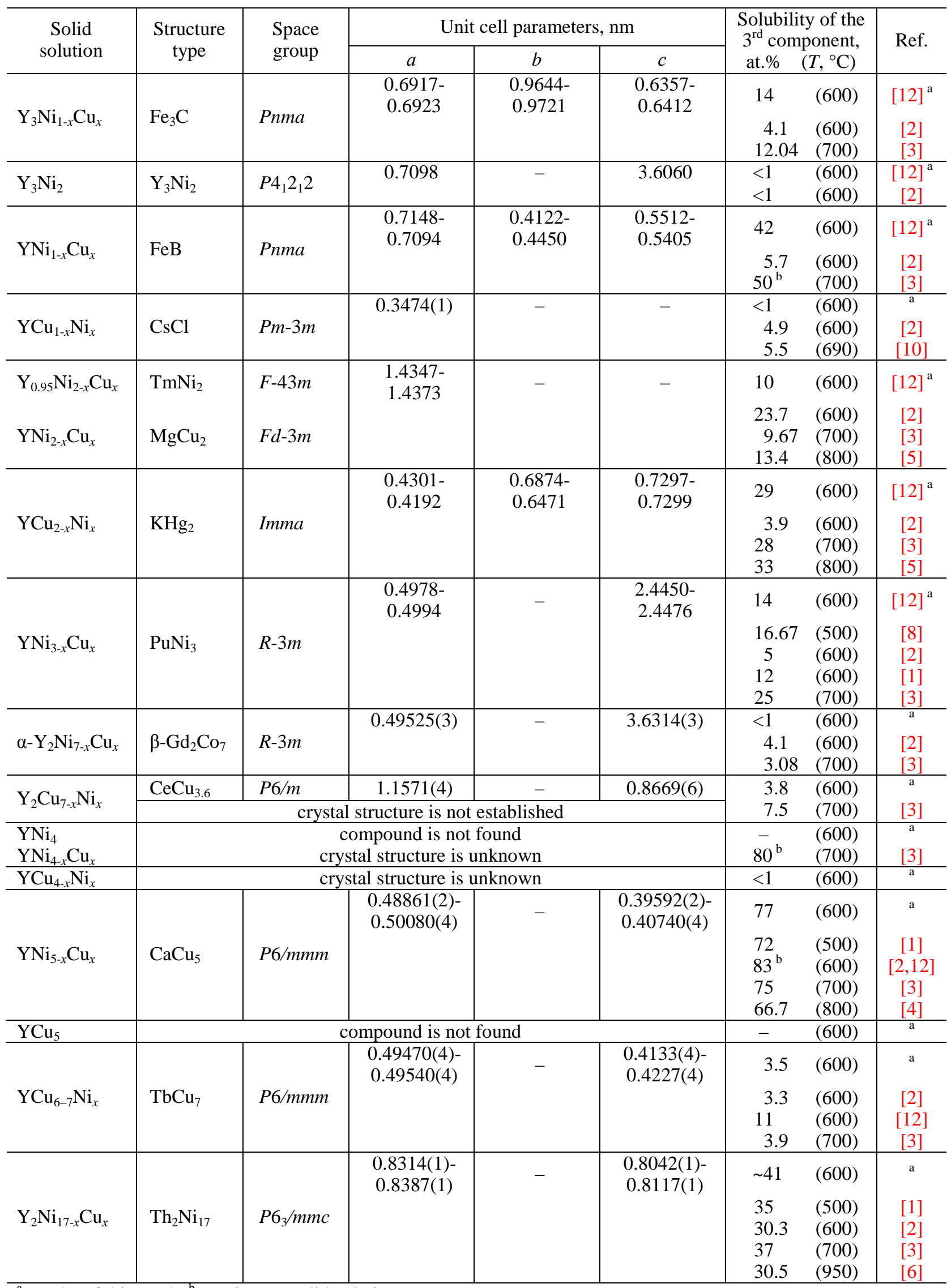

\footnotetext{
${ }^{\mathrm{a}}$ results of this work; ${ }^{\mathrm{b}}$ continuous solid solution
} 
The rhombohedral structure is stable at low temperatures, whereas the hexagonal one is the hightemperature modification. The phase transformation from one type of structure to another occurs via a sluggish martensitic-type process [20]. These structures are closely related, since both are derivatives of the hexagonal $\mathrm{CaCu}_{5}$ structure type [34]. The authors of [18] pointed out that the $\mathrm{YNi}_{2}$ compound has a structure derived from the ideal cubic $\mathrm{MgCu}_{2}$ structure with the defect composition $\mathrm{Y}_{0.95} \mathrm{Ni}_{2}$. It can be described as a superstructure of $\mathrm{MgCu}_{2}$ with doubled $a$ lattice parameter and space group $F-43 m$ with the $4 a$ site only partially occupied by $\mathrm{Y}$ atoms.

The phase equilibria in the $\mathrm{Y}-\mathrm{Cu}$ system have been studied in [25-29]. All the authors confirmed the existence of the intermetallic compounds $\mathrm{YCu}$ (ST $\mathrm{CsCl}$, SG $P m-3 m$ ) and $\mathrm{YCu}_{2}$ (ST $\mathrm{KHg}_{2}$, SG Imma). Some authors reported the existence of a hightemperature modification of the compound $\mathrm{YCu}_{2}$ above $860^{\circ} \mathrm{C}[14,28,29]$ (the structure is unknown). The phase $\mathrm{Y}_{2} \mathrm{Cu}_{7}$ was not found in [25,30,31], however it is present on the phase diagrams of the binary and ternary systems reported in [3,14,26-29,32]. The authors of [32] determined the crystal structure of the $\mathrm{Y}_{2} \mathrm{Cu}_{7}$ compound, which was found to adopt the structure type $\mathrm{CeCu}_{3.6}$ (SG $P 6 / m$, $a=1.1627, c=0.8698 \mathrm{~nm}$ ). According to the data of [25,31], the phase $\mathrm{YCu}_{4}$ with unknown crystal structure exists in a narrow homogeneity range, whereas in [3,14,27-29,32] it is shown as a compound with constant stoichiometric composition. Some authors attribute this phase to the hexagonal structure type $\mathrm{CaCu}_{5}[2,13,26,33]$, while in [32] the crystal structure of $\mathrm{YCu}_{4}$ was determined as an original monoclinic structure type (SG $P 2 / n, a=0.8765$, $\left.b=0.5000, c=0.4105 \mathrm{~nm}, \quad \gamma=91.09^{\circ}\right)$. The phase with $\mathrm{TbCu}_{7}$-type structure (SG $P 6 / \mathrm{mmm}$ ) was in $[14,26,31]$ attributed the composition $\mathrm{YCu}_{7}$, whereas by other researchers [29,31,32] it was reported to occur at the composition $\mathrm{YCu}_{6}$ with a narrow $(<1$ at.\%) homogeneity range.

These inconsistencies in the literature on the compositions and crystal structures of the binary compounds of the $\mathrm{Y}-\mathrm{Ni}$ and $\mathrm{Y}-\mathrm{Cu}$ systems, and on the solubility of the third components in the binary compounds, prompted us to conduct additional research of the system $\mathrm{Y}-\mathrm{Ni}-\mathrm{Cu}$ at $600^{\circ} \mathrm{C}$, the results of which are presented in this article.

\section{Experimental}

The alloys were prepared by arc melting of the elements with not less than 99.9 wt.\% purity under argon. During the arc melting the weight losses were less than $1 \mathrm{wt} . \%$ of the total mass of the ingots. The alloys were annealed in evacuated quartz ampoules at $600^{\circ} \mathrm{C}$ for $1000 \mathrm{~h}$. Bulk and powdered samples were stable in air over months. The annealed binary alloys of the $\mathrm{Y}-\mathrm{Cu}$ system with an $\mathrm{Y}$ content of $\sim 10-30$ at.\% were subjected to re-crystallization. For that purpose 0.5 g-specimens were ground into powder, coldpressed into pellets, separately sealed in evacuated quartz ampoules, and exposed to prolonged thermal annealing at $600^{\circ} \mathrm{C}$ for $4500 \mathrm{~h}$.

The phase analysis of the alloys was carried out with the CSD program package [35] on powder XRD data, obtained with DRON-2.0 (Fe Ka-radiation) and STOE STADI P (Mo $K \alpha_{1}, \mathrm{Cu} K \alpha_{1}$ ) diffractometers. Small and irregularly shaped single crystals were selected from crushed, annealed samples and sealed in Lindemann-glass capillaries under argon atmosphere. These crystals were first examined by the Buerger precession technique in order to establish their quality for subsequent intensity collection. Diffraction data of a crystal were collected at room temperature on a STOE IPDS I image plate diffractometer with monochromatized $\operatorname{Ag~} K \alpha$ radiation and oscillation of the crystal around the $\omega$-axis. The starting atomic parameters were derived by direct methods using the program SIR97 [36] and subsequently refined with the program SHELXL-97 [37] in the WinGX program package [38] (full-matrix least-squares on $F^{2}$ ) with anisotropic atomic displacements.

Metallographic, quantitative and qualitative composition analyses of polished samples and single crystals were performed by energy-dispersive X-ray spectroscopy analysis (EDX) on a scanning electron microscope VEGA TS $5130 \mathrm{MM}$ with an Oxford Si-detector.

\section{Results and discussion}

The isothermal section of the $\mathrm{Y}-\mathrm{Ni}-\mathrm{Cu}$ phase diagram at $600^{\circ} \mathrm{C}$ was investigated by means of XRD and metallographic analyses of 144 binary and ternary alloys and is presented in Fig. 1c.

The existence of the compounds $\mathrm{Y}_{3} \mathrm{Ni}, \mathrm{Y}_{3} \mathrm{Ni}_{2}$, $\mathrm{YNi}, \quad \mathrm{Y}_{1-\delta} \mathrm{Ni}_{2}, \quad \mathrm{YNi}_{3}, \quad \alpha-\mathrm{Y}_{2} \mathrm{Ni}_{7}, \quad \mathrm{YNi}_{5}, \quad$ and $\mathrm{Y}_{2} \mathrm{Ni}_{17}$ was confirmed (see Fig. 1). The solubilities of $\mathrm{Cu}$ observed in these compounds agree with those given in our previous work [12] (see Table 1). Like in our earlier research of the related system $\mathrm{Y}-\mathrm{Zr}-\mathrm{Ni}$ under similar conditions [39], in the present work we encountered a problem regards the $\mathrm{YNi}_{4}$ compound, reported earlier [3,16,22,25]. Based on the results of powder XRD and EDX we conclude that it does not exist at $600^{\circ} \mathrm{C}$. The results of these studies will be given in more detail in a separate publication. It should be noted that one of our previous works was devoted to the refinement of the phase equilibria in the related $\mathrm{Dy}-\mathrm{Ni}$ system concerning the possible existence of a $\mathrm{DyNi}_{4}$ compound, which was also not found [40]. The continuous solid solution between $\mathrm{YNi}_{4}$ and $\mathrm{YCu}_{4}$ at $600^{\circ} \mathrm{C}$ reported in [3], was not confirmed. No significant solubility of the third component in $\alpha-\mathrm{Y}_{2} \mathrm{Ni}_{7}$ was found (see Table 1 ). 
In the present work, the results of [2,12] concerning the existence of a continuous solid solution between $\mathrm{YNi}_{5}(\mathrm{ST} \mathrm{CaCu}$, SG P6/mmm) and $\mathrm{YCu}_{5}$ (attributed to $\mathrm{ST} \mathrm{CaCu}_{5}$ in $[2,13,26,33]$ ) were not confirmed. The pure $\mathrm{YCu}_{5}$ compound is probably not thermodynamically stable at $600^{\circ} \mathrm{C}$ (see below). We refined the homogeneity range of the solid solution $\mathrm{YNi}_{5-x} \mathrm{Cu}_{x}$ : $0 \leq x \leq 4.6$, using EDX technique (see Table 1). A significantly higher solubility of copper ( 41 at.\%), in comparison with previous works, was found in the $\mathrm{Y}_{2} \mathrm{Ni}_{17}$ compound (see Table 1). It may be described by the formula $\mathrm{Y}_{2} \mathrm{Ni}_{17-x} \mathrm{Cu}_{x}(0 \leq x \leq 7.8)$. The variations of the unit cell parameters and the cell volumes within the $\mathrm{YNi}_{5-x} \mathrm{Cu}_{x}(0 \leq x \leq 4.6)$ and $\mathrm{Y}_{2} \mathrm{Ni}_{17-x} \mathrm{Cu}_{x}(0 \leq x \leq 7.8)$ solid solutions are presented in Fig. 2. Substitution of copper for nickel is accompanied by an almost linear change of the unit cell volumes within the solid solutions. The presence of $\mathrm{YCu}$ (ST CsCl, SG $P m-3 m$ )

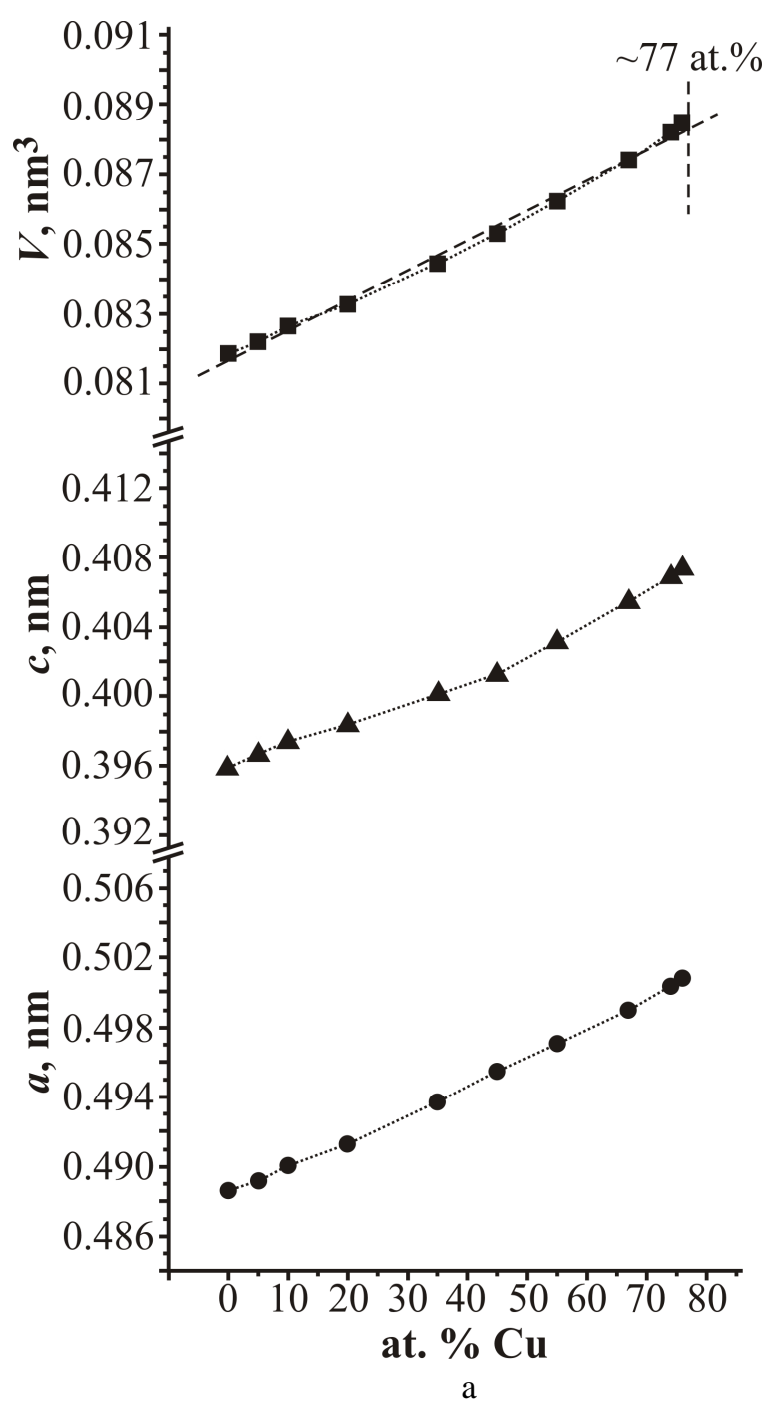

and $\mathrm{YCu}_{2}$ (ST $\mathrm{KHg}_{2}, \quad \mathrm{SG}$ Imma) in the phase equlibria in the $\mathrm{Y}-\mathrm{Ni}-\mathrm{Cu}$ system at $600^{\circ} \mathrm{C}$ was confirmed (see Fig. 1). In [2] two ternary compounds, $\mathrm{YNi}_{0.9-0.7} \mathrm{Cu}_{0.1-0.3}$ (ST FeB, SG Pnma, $a=0.7103$, $b=0.4188, \quad c=0.5491 \mathrm{~nm})$ and $\mathrm{YNi}_{0.3-0.4} \mathrm{Cu}_{0.7-0.6}$ (unknown structure), which are in equilibrium at $600^{\circ} \mathrm{C}$ (Fig. 1a), were reported to occur along the 50 at. $\% \mathrm{Y}$ isoconcentrate. However, according to the data of [3], a continuous solid solution exists between the binary compounds $\mathrm{YNi}$ and $\mathrm{YCu}$ at $700^{\circ} \mathrm{C}$ (see Fig. 1b). In the present investigation we confirmed the results of our previous work [12] on the solubility of copper in the YNi compound (see Table 1). The $\mathrm{YCu}$ compound does not dissolve detectible amounts of nickel. In contradiction with [3], YCu with CsCl-type structure is stable at $600^{\circ} \mathrm{C}$, which makes impossible the formation of a continuous solid solution $\mathrm{YNi}_{1-x} \mathrm{Cu}_{x}$ between $\mathrm{YCu}$ and $\mathrm{YNi}$, the latter crystallizing in another structure type (FeB).

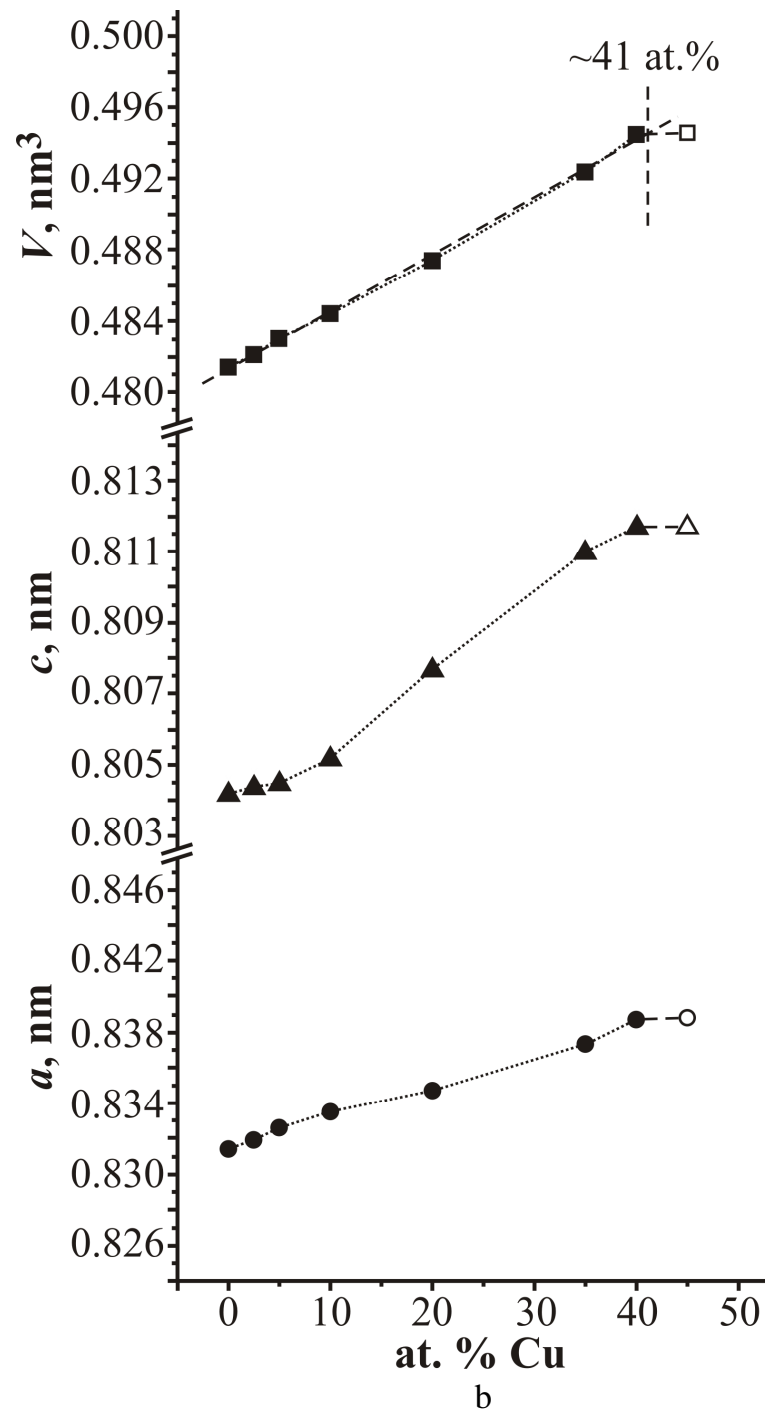

Fig. 2 Variation of the unit cell parameters and cell volumes within the homogeneity ranges $\mathrm{YNi}_{5-x} \mathrm{Cu}_{x}$ $(0 \leq x \leq 4.6)(\mathrm{a}), \mathrm{Y}_{2} \mathrm{Ni}_{17-x} \mathrm{Cu}_{x}(0 \leq x \leq 7.8)(\mathrm{b})$. 
In order to resolve the contradictory literature data on the $\mathrm{Y}-\mathrm{Cu}$ binary compounds reported in [13-15,25-32], special efforts were made to obtain homogenous samples. Prolonged annealing with preliminary grinding of the alloys with an $\mathrm{Y}$ content of $\sim 10-30$ at.\% was applied and the powder was pressed into pellets in order to accelerate recrystallization of the samples. The results of the X-ray phase analysis of as-cast alloys and alloys annealed at $600^{\circ} \mathrm{C}$ indicated the existence in this concentration region of three phases with the following $\mathrm{Y}$ contents: $\sim 14$ at.\% $\left(\mathrm{YCu}_{7}\right), \sim 20$ at.\% $\left(\mathrm{YCu}_{4}\right)$ and $\sim 22$ at.\% $\left(\mathrm{Y}_{2} \mathrm{Cu}_{7}\right)$. According to our data, the $\mathrm{YCu}_{7}$ compound (ST $\mathrm{TbCu}_{7}, \mathrm{SG} \mathrm{P6/mmm)} \mathrm{has} \mathrm{a} \mathrm{narrow} \mathrm{homogeneity}$ range from $\sim 13$ to 15 at. $\% \mathrm{Y}$, which is in good agreement with the data of [31] on as-cast alloys. This result allowed us to assume the $\mathrm{YCu}_{6}$ and $\mathrm{YCu}_{7}$ compounds, reported in $[14,26,29,31,32]$ as different ones, to be the same compound, which we denote here as $\mathrm{YCu}_{6-7}$. It should be noted that the alloys with an $\mathrm{Y}$ content of 19-23 at.\% are very hard and their X-ray diffraction reflections are very blurred, probably due to the existence of internal stresses or defects, which were not removed even after prolonged annealing. In this case mainly the EDX method was used for the determination of the phase equilibria. Backscattered electron images of alloys of the $\mathrm{Cu}$-rich corner of the
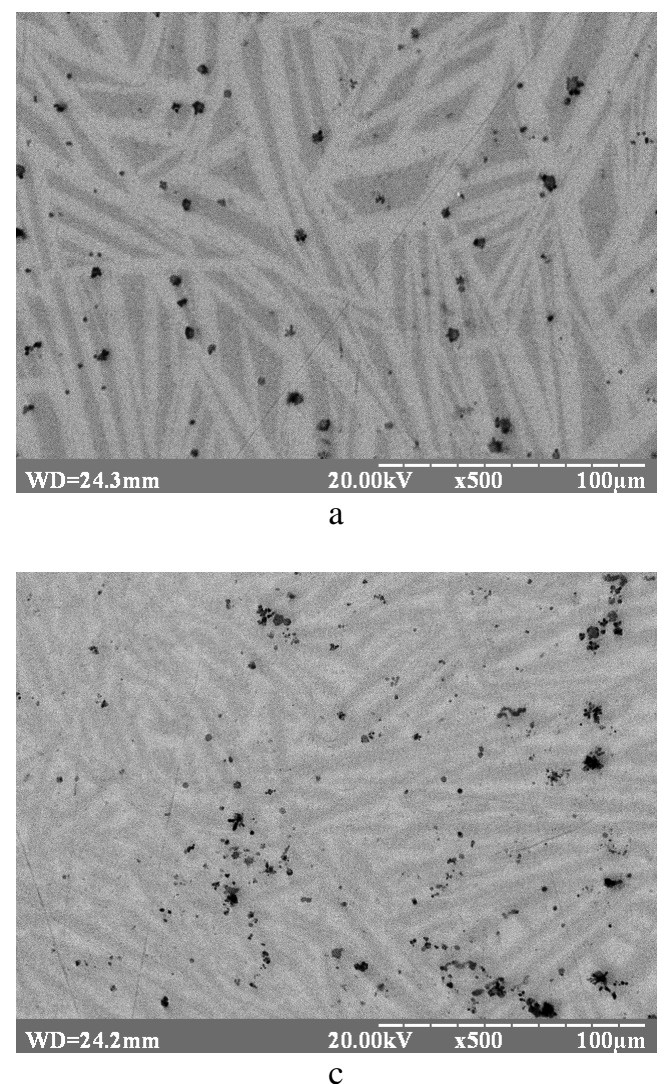

$\mathrm{Y}-\mathrm{Ni}-\mathrm{Cu}$ system annealed at $600^{\circ} \mathrm{C}$ are presented in Fig. 3, and their phase compositions are given in Table 2. The alloy of composition $\mathrm{Y}_{17} \mathrm{Cu}_{83}$, from the presumed homogeneity range of the $\mathrm{YCu}_{4}$ compound [25,31], was found to be a two-phase sample (Fig. 3a, Table 2) and contained the phases $\mathrm{YCu}_{4}$ and $\mathrm{Y}_{2} \mathrm{Cu}_{7}$. The diffuse $\mathrm{X}$-ray powder pattern (Fig. 4a) is very similar to that reported in [28,31]. These authors ascribed the unusual features of the diffractogram to the occurrence of random, non-periodic defects in the parent $\mathrm{CaCu}_{5}$-like type structure. We did not confirm the literature data on the crystal structure of the compound $\mathrm{YCu}_{4}$ : own structure type $(\mathrm{SG} P 2 / n)$ in [32], or structure type $\mathrm{CaCu}_{5}[2,13,26,33]$. The homogeneity range extends from 17 to 20 at.\% $\mathrm{Y}$ at $600^{\circ} \mathrm{C}$. The same sample $\mathrm{Y}_{17} \mathrm{Cu}_{83}$ (see Fig. 3a, Table 2, Fig. 4a) was subjected to re-crystallization. The XRD pattern of the re-crystallized sample is presented in Fig. 4b. Unfortunately, as a result of this treatment it absorbed some oxygen (the presence of $\mathrm{Y}_{2} \mathrm{O}_{3}$ proves this), which, possibly, stabilized the $\mathrm{CaCu}_{5}$-type structure of the main phase (see Fig. 4). The alloy annealed at $600^{\circ} \mathrm{C}$, corresponding to the $\mathrm{Y}_{2} \mathrm{Cu}_{7}$ compound (composition $\mathrm{Y}_{22} \mathrm{Cu}_{78}$ ), was singlephase according to the EDX analysis (Fig. 3b, Table 2). Its powder diffraction pattern (Fig. 5a) could not been indexed due to blurry XRD peaks.
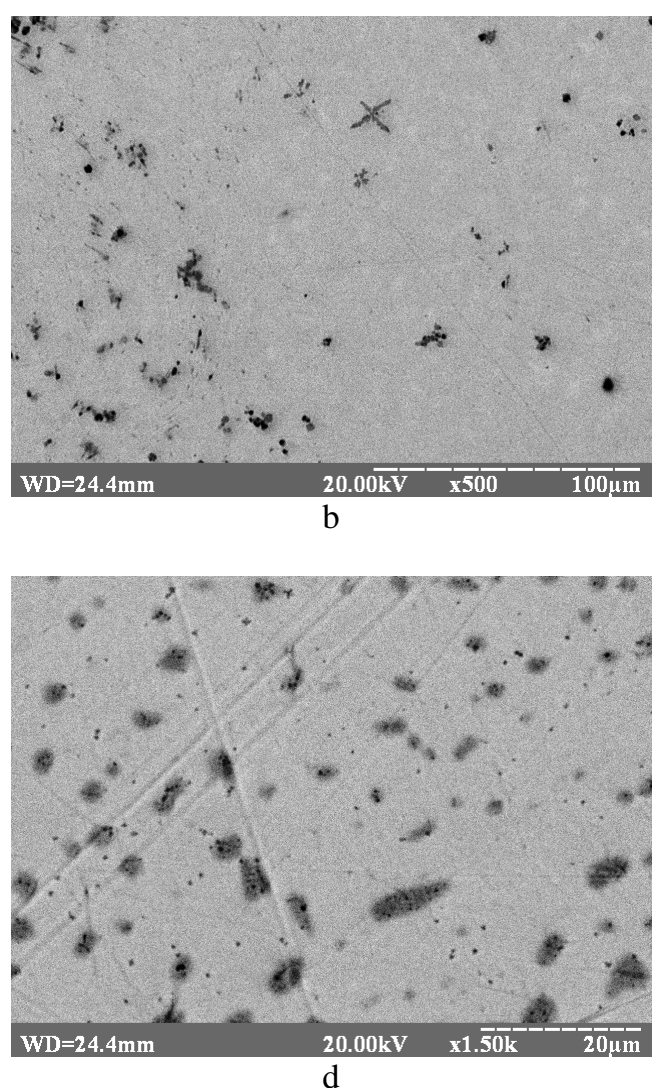

Fig. 3 Backscattered electron image of alloys $\mathrm{Y}_{17} \mathrm{Cu}_{83}$ (a): dark phase - $\mathrm{YCu}_{4}\left(\mathrm{Y}_{17.11} \mathrm{Cu}_{82.89}\right)$, light phase $\mathrm{Y}_{2} \mathrm{Cu}_{7}\left(\mathrm{Y}_{21.5} \mathrm{Cu}_{77.5}\right) ; \mathrm{Y}_{22} \mathrm{Cu}_{78}$ (b): $\mathrm{Y}_{2} \mathrm{Cu}_{7}\left(\mathrm{Y}_{26.15} \mathrm{Cu}_{73.85}\right) ; \mathrm{Y}_{27} \mathrm{Cu}_{68} \mathrm{Ni}_{5}$ (c): dark phase $-\mathrm{Y}_{2} \mathrm{Cu}_{7}\left(\mathrm{Y}_{23.6} \mathrm{Cu}_{72.6} \mathrm{Ni}_{3.8}\right)$, light phase - $\mathrm{YCu}_{2}\left(\mathrm{Y}_{35.3} \mathrm{Cu}_{57.0} \mathrm{Ni}_{7.7}\right) ; \mathrm{Y}_{13} \mathrm{Cu}_{76} \mathrm{Ni}_{11}(\mathrm{~d})$ : light phase - $\mathrm{YNi}_{5}\left(\mathrm{Y}_{16.6} \mathrm{Cu}_{70.6} \mathrm{Ni}_{12.8}\right)$; dark phase - $\mathrm{Cu}$ $\left(\mathrm{Cu}_{98.1} \mathrm{Y}_{1.9}\right)$. 
Table 2 XRD and EDX data for alloys of the $\mathrm{Y}-\mathrm{Cu}$ and $\mathrm{Y}-\mathrm{Cu}-\mathrm{Ni}$ systems.

\begin{tabular}{l|c|c}
\hline $\begin{array}{c}\text { Nominal sample } \\
\text { composition }\end{array}$ & XRD data & EDX data \\
\hline $\mathrm{Y}_{17} \mathrm{Cu}_{83}$ & $\mathrm{YCu}_{4}$ & $\mathrm{Y}_{17.11} \mathrm{Cu}_{82.89}$ \\
\hline $\mathrm{Y}_{22} \mathrm{Cu}_{78}$ & $\mathrm{Y}_{2} \mathrm{Cu}_{7}$ & $\mathrm{Y}_{21.5} \mathrm{Cu}_{77.5}$ \\
\hline $\mathrm{Y}_{27} \mathrm{Cu}_{68} \mathrm{Ni}_{5}$ & $\mathrm{Y}_{2} \mathrm{Cu}_{7}$ & $\mathrm{Y}_{26.15} \mathrm{Cu}_{73.85}$ \\
\hline $\mathrm{Y}_{13} \mathrm{Cu}_{76} \mathrm{Ni}_{11}$ & $\mathrm{Y}_{2} \mathrm{Cu}_{7}$ & $\mathrm{Y}_{23.6} \mathrm{Cu}_{72.6} \mathrm{Ni}_{3.8}$ \\
$\mathrm{YCu}_{2}$ & $\mathrm{Y}_{35.3} \mathrm{Cu}_{57.0} \mathrm{Ni}_{7.7}$ \\
\hline
\end{tabular}

The authors of [3,14,26-29] also failed to determine the crystal structure of $\mathrm{Y}_{2} \mathrm{Cu}_{7}$, and only in [32] the crystal structure of the $\mathrm{Y}_{2} \mathrm{Cu}_{7}$ compound is stated to adopt the structure type $\mathrm{CeCu}_{3.6}(\mathrm{SG} P 6 / m)$. We exposed the $\mathrm{Y}_{22} \mathrm{Cu}_{78}$ alloy to a re-crystallization process. It was found that the $\mathrm{CeCu}_{3.6}$-type of crystal structure of $\mathrm{Y}_{2} \mathrm{Cu}_{7}$ only forms after re-crystallization, as it is shown in Fig. 5b. In this case no oxygen impurities were found, which proves that the structure is not impurity-stabilized, compared to the $\mathrm{CaCu}_{5}$-type structure of $\mathrm{YCu}_{4}$, which is sensitive to oxygen impurities (Fig. 4).

The highest solubility of copper in $\mathrm{Y}_{2} \mathrm{Cu}_{7}$ is 3.8 at. $\%$ at $600^{\circ} \mathrm{C}$, according to the $\mathrm{EDX}$ results (Fig. 3c, Table 2). In [12] the solubility of nickel in $\mathrm{YCu}_{7}$ was reported to be $\sim 11$ at.\%. That is inconsistent with the results of [2,3] (see Table 1). We conducted an EDX analysis of the alloy $\mathrm{Y}_{13} \mathrm{Cu}_{76} \mathrm{Ni}_{11}$ (Fig. 3d, Table 2), which did not reveal the presence of the $\mathrm{YCu}_{7}$ phase in the sample, indicating a significantly lower solubility of nickel in $\mathrm{YCu}_{7}$, which does not exceed 3.5 at. $\%$ at $600^{\circ} \mathrm{C}$. The $\mathrm{YCu}_{4}$ phase does practically not dissolve the third component in the $\mathrm{Y}-\mathrm{Ni}-\mathrm{Cu}$ system at $600^{\circ} \mathrm{C}$.

One ternary compound, with the extended homogeneity range $\mathrm{YNi}_{2.85-0.75} \mathrm{Cu}_{1.15-3.25}$, was found to occur in the $\mathrm{Y}-\mathrm{Ni}-\mathrm{Cu}$ system along the 20 at.\% Y isoconcentrate at $600^{\circ} \mathrm{C}$. We failed to determine its crystal structure as the powder XRD profile was very blurred. This is probably due to the existence of internal stresses or defects, which were not removed even after prolonged annealing procedure at $1000^{\circ} \mathrm{C}$. Our attempts to find single crystals of the new compound failed. Instead of the new compound (which was the main phase in the sample), a single crystal within the homogeneity range of the $\mathrm{YNi}_{5-x} \mathrm{Cu}_{x}$ $(0 \leq x \leq 4.6)$ solid solution was extracted from a crushed sample of composition $\mathrm{Y}_{20} \mathrm{Ni}_{60} \mathrm{Cu}_{20}$ (annealed at $1000^{\circ} \mathrm{C}$ ). The composition $\mathrm{YNi}_{4} \mathrm{Cu}$ was found by EDX analysis. Single-crystal XRD data confirmed that the crystal structure was of the $\mathrm{CaCu}_{5}$ structure type. All relevant crystallographic data are listed in Table 3. The atomic coordinates and displacement parameters for the $\mathrm{YNi}_{4} \mathrm{Cu}$ single crystal are gathered in Table 4 and 5, respectively. The results of the investigation indicated that the Wyckoff positions $1 a$ and $3 g$ are fully occupied by $\mathrm{Y}$ and $\mathrm{Ni}$ atoms, respectively, and the $2 c$ site is occupied by a statistical mixture of 25 at. $\% \mathrm{Ni}+75$ at. $\% \mathrm{Cu}$. In this case we obtained satisfactory values of the displacement parameters and the lowest $R$-values. As one can see from Table 1, the concentration ranges of the solid solutions in the $\mathrm{Y}-\mathrm{Ni}-\mathrm{Cu}$ system vary at different temperatures of annealing. Comparing the results of the present investigation with the data of investigations of alloys annealed at different temperatures $[1,3-6,8,10]$, it appears that an increase of the annealing temperature leads to an increase of the solubility of the third component in the binary compounds of the $\mathrm{Y}-\mathrm{Ni}$ and $\mathrm{Y}-\mathrm{Cu}$ systems (Table 1). Replacement of $\mathrm{Ni}$ atoms $(r=0.124 \mathrm{~nm})$ by larger $\mathrm{Cu}$ atoms $(r=0.128 \mathrm{~nm})$ leads to an increase of the unit cell parameters and of the unit cell volumes of alloys within the homogeneity ranges of the solid solutions. The variation of the unit cell parameters is, however, non-linear [3-6,12]. There are both slight positive and negative deviations from Vegard's rule.

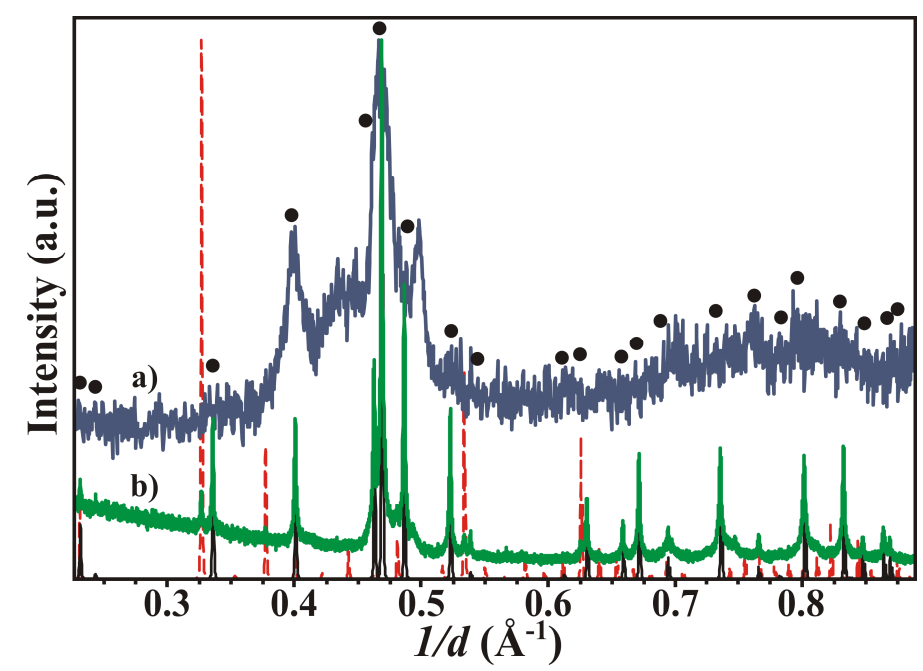

Fig. 4 XRD patterns of the $\mathrm{Y}_{17} \mathrm{Cu}_{83}$ sample: a) annealed at $600^{\circ} \mathrm{C}$ (unknown structure); b) after re-crystallization ( $\mathrm{ST} \mathrm{CaCu}_{5}$ (bottom, solid lines; positions of peaks indicated by circles) and $\mathrm{Y}_{2} \mathrm{O}_{3}$ (bottom, dashed lines)). 


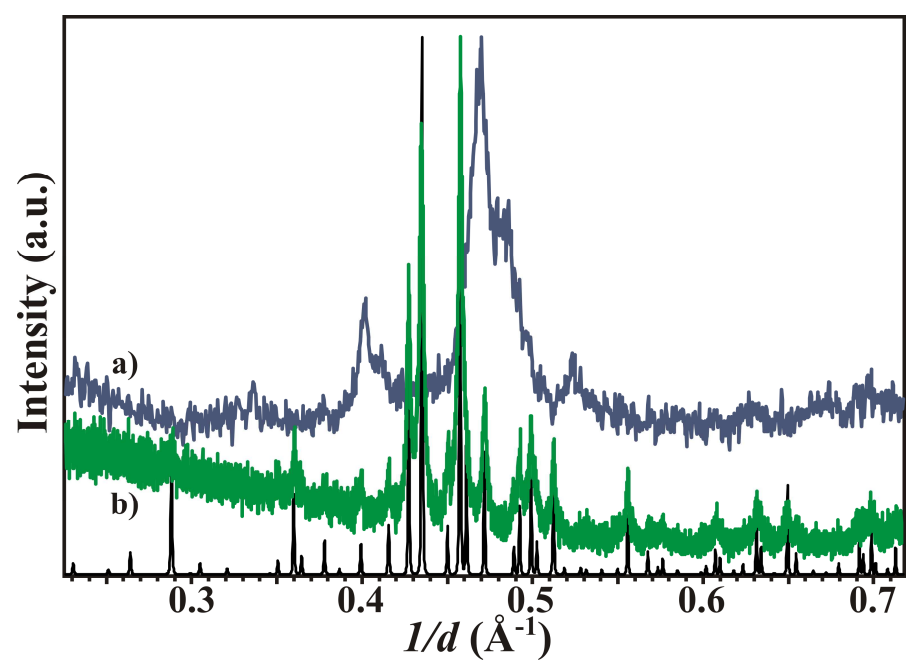

Fig. 5 XRD patterns of the $\mathrm{Y}_{22} \mathrm{Cu}_{78}$ sample: a) annealed at $600^{\circ} \mathrm{C}$ (unknown structure); b) after re-crystallization (ST $\mathrm{CeCu}_{3.6}, \mathrm{SG} P 6 / m$ (bottom)).

Table 3 Crystal and structure refinement data for $\mathrm{YNi}_{4} \mathrm{Cu}$.

\begin{tabular}{|c|c|}
\hline $\begin{array}{l}\text { Empirical formula } \\
\text { Space group } \\
Z \\
\text { Unit cell parameters } \\
a, \mathrm{~nm} \\
c, \mathrm{~nm} \\
\text { Unit cell volume, } \mathrm{nm}^{3} \\
\text { Calculated density, } \mathrm{g}^{3} \mathrm{~cm}^{3} \\
\text { Absorption coefficient, } \mathrm{mm}^{-1} \\
\text { Crystal size, } \mathrm{mm}^{3} \\
\text { Radiation and wavelength, nm } \\
\text { Diffractometer } \\
\text { Refined parameters } \\
\text { Refinement } \\
2 \theta_{\text {max }} \\
h, k, l \\
\text { Collected reflections } \\
\text { Independent reflections } \\
\text { Reflections with } I_{\mathrm{o}} \geq 2 \sigma\left(I_{\mathrm{o}}\right) \\
\text { Final } R_{1} \text { indices }\left(R_{1} \text { all data }\right)^{\mathrm{a}} \\
\text { Weighted } w R_{2} \text { factor }\left(w R_{2} \text { all data }\right)^{\mathrm{b}} \\
\text { Goodness-of-fit on } F^{2} \\
\text { Extinction coefficient } \\
\text { Largest difference peak and hole } /\left(e \cdot \AA^{-3}\right)\end{array}$ & $\begin{array}{l}\mathrm{YNi}_{4} \mathrm{Cu} \\
P 6 / m m m \\
1 \\
0.4899(2) \\
0.3979(3) \\
0.0827(1) \\
7.776 \\
24.219 \\
0.12 \times 0.08 \times 0.03 \\
\mathrm{Ag} \mathrm{K \alpha}, 0.056086 \\
\mathrm{STOE} \mathrm{IPDS} \mathrm{I} \\
11 \\
F^{2} \\
46.72 \\
-6<h<6 \\
-6<k<6 \\
-5<l<5 \\
931 \\
65\left(R_{\text {int }}=0.087\right) \\
57\left(R_{\sigma}=0.035\right) \\
0.028(0.039) \\
0.058(0.062) \\
1.22 \\
0.08(2) \\
2.0 /-2.7\end{array}$ \\
\hline
\end{tabular}

${ }^{\mathrm{a}} R_{1}(F)=\left[\Sigma\left(\left|F_{\mathrm{o}}\right|-\left|F_{\mathrm{c}}\right|\right)\right] / \Sigma\left|F_{\mathrm{o}}\right|$

${ }^{\mathrm{b}} w R_{2}\left(F^{2}\right)=\left[\Sigma\left[w\left(F_{\mathrm{o}}{ }^{2}-F_{\mathrm{c}}\right)^{2} / \Sigma\left[w\left(F_{\mathrm{o}}{ }^{2}\right)^{2}\right]\right]^{1 / 2}\right.$

Table 4 Atomic coordinates and displacement parameters $\left(\times 10^{2} \mathrm{~nm}^{2}\right)$ for $\mathrm{YNi}_{4} \mathrm{Cu}$.

\begin{tabular}{c|c|c|c|c|c}
\hline Atom & Site & $x$ & $y$ & $z$ & $U_{\mathrm{eq}}$ \\
\hline $\mathrm{Y}$ & $1 a$ & 0 & 0 & 0 & $0.0080(5)$ \\
$\mathrm{Ni}$ & $3 g$ & $1 / 2$ & 0 & $1 / 2$ & $0.0052(5)$ \\
$M$ & $2 c$ & $2 / 3$ & $1 / 3$ & 0 & $0.0065(2)$ \\
\hline
\end{tabular}

$M=0.25 \mathrm{Ni}+0.75 \mathrm{Cu}$ 
Table 5 Anisotropic displacement parameters ${ }^{\mathrm{a}}\left(\times 10^{2} \mathrm{~nm}^{2}\right)$ for $\mathrm{YNi}_{4} \mathrm{Cu}$.

\begin{tabular}{ccccc}
\hline Atom & $U_{11}$ & $U_{22}$ & $U_{33}$ & $U_{12}$ \\
\hline $\mathrm{Y}$ & $0.0049(6)$ & $0.0049(6)$ & $0.0142(9)$ & $0.0024(3)$ \\
$\mathrm{Ni} 1$ & $0.0058(6)$ & $0.0018(7)$ & $0.0067(8)$ & $0.0009(4)$ \\
$\mathrm{Ni} 2$ & $0.0055(3)$ & $0.0055(3)$ & $0.001(2)$ & $0.0027(3)$ \\
$\mathrm{Cu}$ & $0.0065(2)$ & $0.0065(2)$ & $0.0065(2)$ & $0.0032(4)$ \\
\hline
\end{tabular}

${ }^{\mathrm{a}} U_{13}=U_{23}=0$

The $\mathrm{Y}-\mathrm{Ni}-\mathrm{Cu}$ system studied here is similar to other $R E-\mathrm{Ni}-\mathrm{Cu}(R E=\mathrm{Gd}, \mathrm{Dy}, \mathrm{Ho})$ systems [41-43] in many aspects. All these systems are characterized by the formation of ternary compounds at a low (20-25 at.\%) $R E$ content and the presence of solid solutions of $\mathrm{Cu} / \mathrm{Ni}$ substitution based on $\mathrm{Y}-\mathrm{Ni}$ and $\mathrm{Y}-\mathrm{Cu}$ binary compounds.

\section{Conclusions}

The phase equilibria in the $\mathrm{Y}-\mathrm{Ni}-\mathrm{Cu}$ ternary system and the $\mathrm{Y}-\mathrm{Ni}$ and $\mathrm{Y}-\mathrm{Cu}$ binary systems at $600^{\circ} \mathrm{C}$ have been re-investigated in order to resolve some controversial data on compositions and crystal structures of binary and ternary phases. The presence of the $\mathrm{YNi}_{4}$ compound at $600^{\circ} \mathrm{C}$ was not confirmed. The homogeneity ranges of the solid solutions $\mathrm{YNi}_{5-x} \mathrm{Cu}_{x} \quad(0 \leq x \leq 4.6), \quad \mathrm{Y}_{2} \mathrm{Ni}_{17-x} \mathrm{Cu}_{x} \quad(0 \leq x \leq 7.8)$, $\mathrm{YCu}_{6-7} \mathrm{Ni}_{x}(0 \leq x \leq 0.28)$ were refined. The maximal solubility of the third component does not exceed 3.8 at. $\%$ in $\mathrm{Y}_{2} \mathrm{Cu}_{7}$ and is less than 1 at.\% in $\mathrm{Y}_{2} \mathrm{Ni}_{7}$, $\mathrm{YCu}$, and $\mathrm{YCu}_{4}$. The crystal structure of a single crystal of composition $\mathrm{YNi}_{4} \mathrm{Cu}\left(\mathrm{CaCu}_{5}\right.$-type structure, $\mathrm{YNi}_{5-x} \mathrm{Cu}_{x}$ solid solution) was investigated by single-crystal $\mathrm{X}$-ray diffraction. One new ternary compound with an extended homogeneity range, $\mathrm{YNi}_{2.85-0.75} \mathrm{Cu}_{1.15-3.25}$, was found to occur in the $\mathrm{Y}-\mathrm{Ni}-\mathrm{Cu}$ system at $600^{\circ} \mathrm{C}$. Its crystal structure is unknown.

A long-time special procedure for recrystallization was needed to reach equilibrium state for the $\mathrm{Y}-\mathrm{Ni}$ and $\mathrm{Y}-\mathrm{Cu}$ samples in the 15-25 at.\% Y region. After this treatment, the $\mathrm{Y}_{2} \mathrm{Cu}_{7}$ compound with $\mathrm{CeCu}_{3.6}$-type structure and the $\mathrm{YCu}_{6-7}$ compound (unknown structure) were obtained.

The previously reported $\mathrm{YCu}_{5}$ and $\mathrm{YCu}_{4}$ compounds crystallizing in $\mathrm{CaCu}_{5}$-type structures are stabilized by oxygen.

\section{Acknowledgements}

The authors gratefully thank H. Gärtling (MPI FKF Stuttgart, Germany) for XRD data collection, V. Duppel (MPI FKF Stuttgart, Germany) and R. Serkiz (Technical and Educational Center of LowTemperature Studies, Ivan Franko National University of Lviv, Ukraine) for EDX analysis.

\section{References}

[1] J. Zheng, L. Nong, Acta Metall. Sin. 21 (1985) 58-61.

[2] O.I. Kharchenko, L.M. Kondratyuk, M.M. Rak, Visn. Lviv. Univ., Ser. Khim. 7 (1986) 50-52.

[3] M. Mezhabul-Islam, M. Medraj, J. Alloys Compd. 561 (2013) 161-173.

[4] A.E. Dwight, J. Less-Common Met. 43 (1975) 121-128.

[5] Paul-Boncour, A. Lindbaum, E. Gratz, E. Leroy, A. Percheron-Guégan, Intermetallics 10 (2002) 1011-1017.

[6] P.D. Carfagna, W.E. Wallace, R.S. Craig, J. Solid State Chem. 2 (1970) 1-5.

[7] I.Yu. Zavaliy, R. Cerny, V.N. Verbetsky, R.V. Denys, A.V. Riabov, J. Alloys Compd. 358 (2003) 146-151.

[8] V.V. Burnasheva, B.P. Tarasov, Zh. Neorg. Khim. 29 (1984) 1136-1141.

[9] O. Myakush, Yu, Verbovytsky, O. Myagkota, I. Koval'chuk, V. Berezovets', B. Kotur, Visn. Lviv. Univ., Ser. Khim. 49 (2008) 128-136.

[10] H. Kadomatsu, Y. Kawanishi, M. Kurisu, J. Less-Common Met. 141 (1988) 29-36.

[11] O. Myakush, V. Babizhetskyy, P. Myronenko, H. Michor, E. Bauer, B. Kotur, Chem. Met. Alloys 4 (2011) 152-159.

[12] N. Pyk, P. Myronenko, N. Bykalovych, O. Myakush, B. Kotur, Visn. Lviv. Univ., Ser. Khim. 51 (2010) 79-87.

[13] T.V. Massalski, H. Okamoto, P.R. Subramanian, L. Kacprzak (Eds.), Binary Alloy Phase Diagrams, ASM, Materials Park, Ohio, 1990.

[14] H. Okamoto (Ed.), Phase Diagrams for Binary Alloys, ASM, Materials Park, Ohio, 2000.

[15] P. Villars, K. Cenzual (Eds.), Pearson's Crystal Data, Crystal Structure Database for Inorganic Compounds, ASM, Materials Park, Ohio, 2001.

[16] B.J. Beaudry, A.H. Daane, Trans. Metall. Soc. AIME 218(1960) 854-859.

[17] K.H.J. Buschow, J. Less-Common Met. 11 (1966) 204-208.

[18] M. Latroche, V. Paul-Boncour, A. PercheronGuégan, J.C. Achard, Eur. J. Solid State Inorg. Chem. 28 (1991) 597-600.

[19] A.V. Virkar, A. Raman, J. Less-Common Met. 18 (1969) 59-66. 
[20] K.H.J. Buschow, A.S. van der Goot, J. LessCommon Met. 22 (1970) 419-428.

[21] D.T. Cromer, A.C. Larson, Acta Crystallogr. 12 (1959) 855-859.

[22] P. Nash, Phase Diagrams of Binary Nickel Alloys, ASM, Materials Park, Ohio, 1991.

[23] K.H.J. Buschow, Rep. Prog. Phys. 40 (1977) 1179-1256.

[24] C. Colinet, A. Pasture, K.H.J. Bushow, J. Appl. Phys. 62 (1987) 3712-3717.

[25] F. Domagala, J.J. Rausch, D.W. Levinson, Trans. Am. Soc. Met. 53 (1961) 137-155.

[26] K.H.J. Buschow, A.S. van der Goot, Acta Crystallogr. B 27 (1971) 1085-1088.

[27] K. Itagaki, G. Qi, S. An Mey, P.J. Spencer, CALPHAD 14 (1990) 377-384.

[28] S.G. Fries, H.L. Lukas, R. Konetzki, R. SchmidFetzer, J. Phase Equilib. 15 (1994) 606-614.

[29] M. Mezbahul-Islam, D. Kevorkov, M. Medraj, J. Chem. Thermodyn. 40 (2008) 1064-1076.

[30] L. Romaka, I. Romaniv, Yu. Stadnyk, V. Romaka, R. Serkiz, R. Gladyshevskii, Chem. Met. Alloys 7 (2014) 132-138.

[31] O. Zaremba, A. Saccone, S. De Negri, F. Merlo, R. Gladyshevskii, Fiz. Khim. Tverd. Tila 9 (2008) 569-576.

[32] N. Belyavina, V. Markiv, O. Nakonechna, J. Alloys Compd. 541 (2012) 288-295.
[33] K.P. Gupta, J. Phase Equilib. Diffus. 10 (2009) 1547-1563.

[34] E. Parthé, B.A. Chabot, K. Cenzual, Chimia 39 (1985) 164-174.

[35] L. Akselrud, Y. Grin, J. Appl. Crystallogr. 47 (2014) 803-805.

[36] A. Altomare, M.C. Burla, M. Camalli, B. Carroccini, G.L. Cascarano, C. Giacovazzo, A. Guagliardi, A.G. Moliterni, G. Polidori, R. Rizzi, J. Appl. Crystallogr. 32 (1999) 115119.

[37] G.M. Sheldrick, SHELXL-97: Program for the Refinement of Crystal Structures, University of Göttingen, Germany, 1997.

[38] L.G. Farrugia, J. Appl. Crystallogr. 32 (1999) 837-838.

[39] V. Babizhetskyy, O. Myakush, B. Kotur, A. Simon, Intermetallics 38 (2013) 44-48.

[40] V. Levytskyy, V. Babizhetskyy, B. Kotur, Visn. Lviv. Univ., Ser. Khim. 55 (2014) 12-20.

[41] Zh. Huaiying, Zh. Yinghong, G. Zhengfei, J. Alloys Compd. 221 (1995) 98-101.

[42] D. Li, J. Zheng, Acta Metall. Sin. Engl. Ed., Ser. $B 2$ (1989) 426-427.

[43] Zh. Yinghong, Zh. Liping, J. Less-Common Met. 170 (1991) 223-229. 